\title{
Antagonism Test of Trichoderma atroviride and Gliocladium sp. Bali Local Isolates As a Disease Control of Blendok Disease (Botryodiplodia theobromae) in Grapefruit (Citrus grandis L. Osbeck)
}

\author{
Krisnawan Kalimutu모 Ida Bagus Komang Mahardika², Anak Agung Sagung Putri Risa \\ Andriani $^{3}$ \\ Agrotechnology Department, Faculty of Agriculture, Warmadewa University, Indonesia \\ ${ }^{1}$ E-mail: krisnawankalimutu@gmail.com \\ 2 E-mail: gusmahardika62@gmail.com \\ ${ }^{3}$ E-mail: putri_risa69@yahoo.com
}

\begin{abstract}
This study aims to determine the ability of Trichoderma atroviride and Gliocladium sp. in inhibiting the fungus that causes Gumosis disease Botryodiplodia theobromae. This study used a completely randomized design with two single treatments and was repeated eight times. In the in-vitro antagonism test Trichoderma atroviride and Gliolcadium sp. can inhibit the fungus Botryodiplodia theobromae as well. The percentage of inhibition was $94.58 \%$ in the Trichoderma atroviride antagonism test and $81.67 \%$ in the Gliocladium sp. antagonism test. Whereas the Botryodiplodia theobromae Colony Area had no significant effect on both treatments. Each Botryodiplodia theobromae Colony area is $18.34 \mathrm{~cm}^{2}$ with T. atroviride treatments and $22.25 \mathrm{~cm}^{2}$ with Gliocladium sp. treatment. The growth rate of Botryodiplodia Theobroma fungi was superior to that of Trichoderma atroviride and Gliocladium $s p$.
\end{abstract}

Keywords: Trichoderma atroviride, Gliocladium sp, Botryodiplodia theobromae, and Blendok disease

\section{Introduction}

Grapefruit (Citrus grandis L. Osbeck) is native citrus originating from Indonesia and spread throughout Southeast Asia and also to several countries. Grapefruit also has various names in each region in Indonesia. The names in each region for this type of citrus vary, namely Jeruk Pandan, Jeruk Sinyonya, Jeruk Cikoneng, Jeruk Nambangan, Jeruk Delima, Jeruk Silempang, Jeruk Oyod Gondong, Jeruk Nambangan-Madiun, Jeruk Bali, Jeruk Gulung, Jeruk Pandanwangi [1]. Grapefruit in Balinese speaking is called Jerungge. This orange is the largest citrus species that has a thick skin and large pulp. Grapefruit is usually cultivated in the yard of Balinese people as a yard fruit plant that has fragrant flowers so that the yard becomes fresher.

One of the constraints in citrus cultivation is a disease attack. One of these diseases is blendok disease caused by the fungus Botryodiplodia theobromae [2]. This attack causes injury to the skin of the grapefruit plant and the emergence of a yellow liquid which will harden over time so that it forms crystals with a brownish yellow color which tends to be darker. Symptoms of this disease are called gumosis and the discharge in the form of mucus is called gum. Gumosis is the response of citrus plants to infection from pathogens on infected plant stems [3].

The use of biological agents Trichoderma $s p$. and Gliocladium $s p$. in the control of plant diseases is specific, which means that these biological agents have adapted to the place and have been around for a long time. Biological control is locally specific, namely biological agents as pathogenic antagonists found in a place will only give good results in the place where the fungal 
isolates were obtained. The ability of each species Trichoderma sp. In suppressing the growth of different pathogenic fungi, due to different morphology and physiology in producing toxic compounds [4].

The antagonistic properties of the fungus Trichoderma sp. have been researched for a long time and can suppress diseases in plants. Trichoderma spp. This can parasitize plant pathogenic fungi that can attack and take nutrients from other fungi. and is antagonistic because it can kill or inhibit the growth of pathogenic fungi. The addition of Trichoderma sp. into the soil can suppress pathogenic fungi, this is due to the influence of toxins produced by this fungus which can be isolated from cultures grown in vitro. Secondary metabolites Trichoderma spp. can be in the form of antibiotics, enzymes, toxins, and hormones. Antibiotic compounds produced by Trichoderma spp. among them are viridins, kininginins, cytosperone, trichodermol, mannitol, and 2hydroximalonic acid [5]. Types of Trichoderma that are commonly found in Indonesia are Trichoderma piluliferum, Trichoderma polysporum, Trichoderma hamatum, Trichoderma koningii, Trichoderma aureoviride, Trichoderma harzianum, Trichoderma longibrachiatum, Trichoderma Viride [6]. Gliocladium sp. is a pathogenic antagonistic fungus that can control various diseases that infect plants and are saprophytic. So that this fungus has the potential to be used as a biological agent to control blendok disease because it produces metabolite compounds, namely gliotoxin, and viridian, which is fungi toxic against plant pathogenic fungi. The impact of the resulting metabolite compounds on pathogens can be in the form of inhibition or cessation of the growth of pathogenic fungi, reduction or cessation of pathogenic fungal sporulation, and even reduction of the viability of pathogenic fungi. This can be accompanied by various deviations in the growth of hyphae in fungi, for example changing the pattern of colony germination and a decrease in the metabolism of other damaged fungi [7]. Gliocladium sp. is scattered in various types of soil such as forest land and agricultural land which has a variety of vegetation. The nutritional requirements of necrotic antagonistic fungi are not different from saprotrophic fungi. Gliocladium $s p$ is easily found in the soil, but in very small amounts so it does not have the desired effect. The optimum growth of the fungus Gliocladium spp. occurs at a temperature of $25^{\circ} \mathrm{C}-32^{\circ} \mathrm{C}$. This necrotic parasitic fungus can grow well as a saprotrophic competitor from other fungi and is also very tolerant of $\mathrm{CO}_{2}$ [7].

\section{Materials and Methods}

\subsection{Place and Time}

This research was conducted at the Center for Food Crops and Horticulture Protection, Bali Province. From March 30, 2020, to July 7, 2020.

\subsection{Materials Research}

The materials used in this study were soil samples from the rhizosphere of rice and citrus plants, plant skins attacked by B. theobromae, Potato Dextrose Agar (PDA), potatoes, agar, sucrose, $70 \%$ alcohol, distilled water, and antibiotics (Chloramphenicol).

The tools used in this study were plastic samples, hoes, scales, Petri dishes, Erlenmeyer tubes, test tubes, Bunsen, laminar airflow, measuring cups, ent needles, dropper pipettes, aluminum foil, plastic wrap, label paper, trays, jars, gauze, heat-resistant plastics, autoclaves, cameras, scales, and stationery. 


\subsection{Research Method}

This study used a dual culture method [8] and a completely randomized design (CRD) consisting of two treatments, namely Trichoderma $s p$. and Gliocladium sp. Each treatment was repeated eight times.

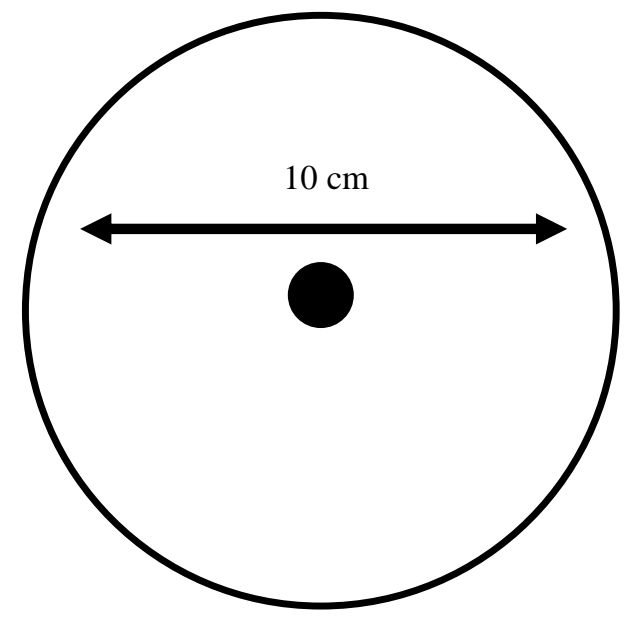

a

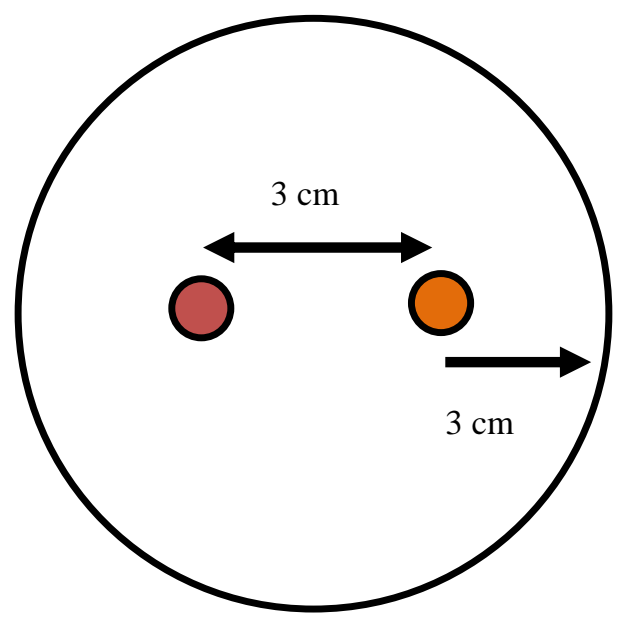

b

Information :

: Single inoculation of test fungi (Trichoderma sp., Gliocladium sp. And Botryodiplodia theobromae) to observe the growth rate

: : Biological control agents (Trichoderma sp. or Gliocladium sp.)

: Botryodiplodia theobromae

Figure 1.

(a) Fungi that are single inoculated, (b) Treatment of Botryodiplodia theobromae

\subsection{Data Collection Technique}

Data sourced from primary data and secondary data. Primary data were taken by observing directly the colony area measurement every day to find the growth rate and measurement of each fungal growth on the radius of the fungal colony per day after inoculation. Secondary data were obtained from literature studies from various sources both books and previous research journals.

\subsection{Research variable}

The variables observed in this study were:

\subsubsection{Colony Area}

The colony area of $B$. theobromae on the seventh day by measuring the area of the colony that had not been covered by antagonistic fungi. Measured by drawing the colony area on the millimeter block, then the total area of each fungal colony is calculated.

\subsubsection{Growth Rate}

The growth rate of the fungus was measured using a ruler by measuring the colony diameter of each mushroom every day then the colony area was calculated using the circular area formula after inoculation to cover the petri dish.

\subsubsection{Antagonism Mechanism}

Antagonism mechanisms [9] includes: 
a. Competition.

Competition between test fungi and pathogenic fungi for space and nutrition. Observed by looking at the type of fungus that fills the petri dish faster.

b. Antibiosis.

Antibiosis observation is done by looking at the presence or absence of color changes on PDA media due to metabolites produced by the test fungi.

c. Parasitism.

Observation of the mechanism of parasitism was carried out by observing the tested antagonistic fungal hyphae growing on pathogenic fungi. You do this by taking the hyphae of the two fungi using a loop needle, then placing them on the slide to be observed microscopically.

\subsubsection{Percentage of Inhibition}

The percentage of inhibition was calculated on the 14th day after inoculation with the formula of Fokkema and Meuleun (1976):

$$
\mathrm{I}(\%)=\frac{R 1-R 2}{R 1} \times 100 \%
$$

Keterangan :

I: Inhibition (\%)

R1: The colonies of Botryodiplodia theobromae away from the colony of the test antagonist fungi

R2: The colonies of Botryodiplodia theobromae are close to the colony of the test antagonist fungi

\subsection{Data Analysis}

Observation of the inhibition test was carried out every day until the 7th day. The data obtained were then analyzed for a variance with the IBM SPSS Statistics version 26 statistical program. Furthermore, the data will be tested by the Independent T-test and then described according to the results of the data obtained.

\section{Results and Discussion}

\subsection{Isolates Identification}

Isolate Trichoderma sp. is Trichoderma atroviride by showing around colony shape, green with slightly yellowish color, and white mycelia. Conidiophores are unilateral and usually paired. The shape of the phialides is straight or tortuous, cylindrical, narrow at the end of the phialides, and has oval conidia [11] [12].
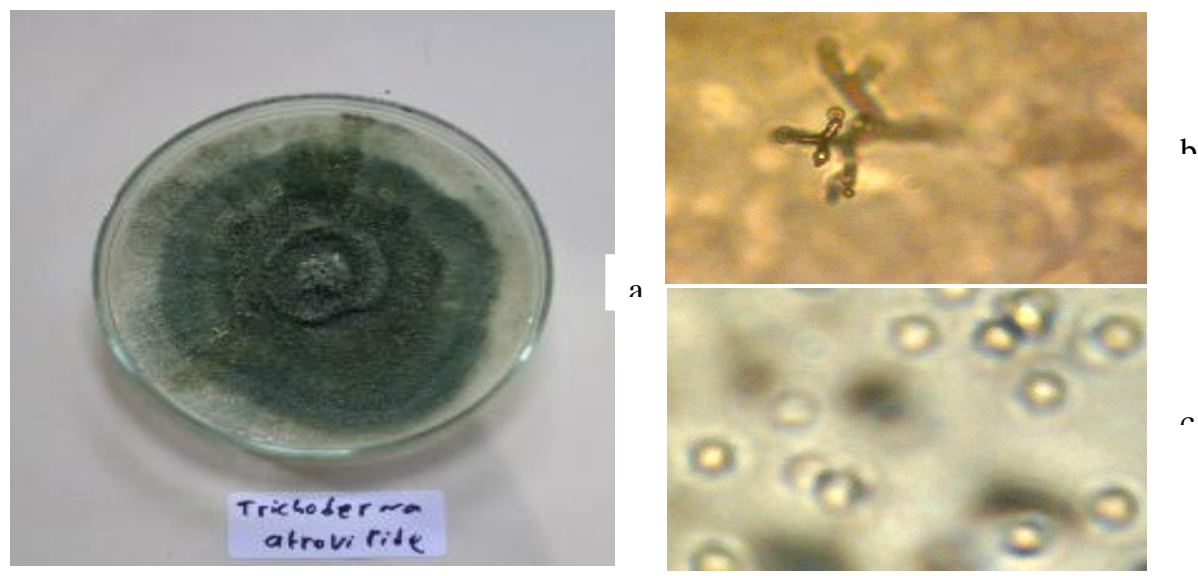

Figure 2.

(a) Colonies on PDA, (b) form fhialides and (c) form conidia 

Disease (Botryodiplodia theobromae) in Grapefruit (Citrus grandis L. Osbeck)

Gliocladium $s p$. isolate shows the morphology of Gliocladium sp. has a colony of green spots on the spores according to the morphology [13]. Conidiophores with septa and brush-shaped phialides similar to Penicillium sp. The apex is branched and perpendicular, conidia appear on the primary branches and are oval.
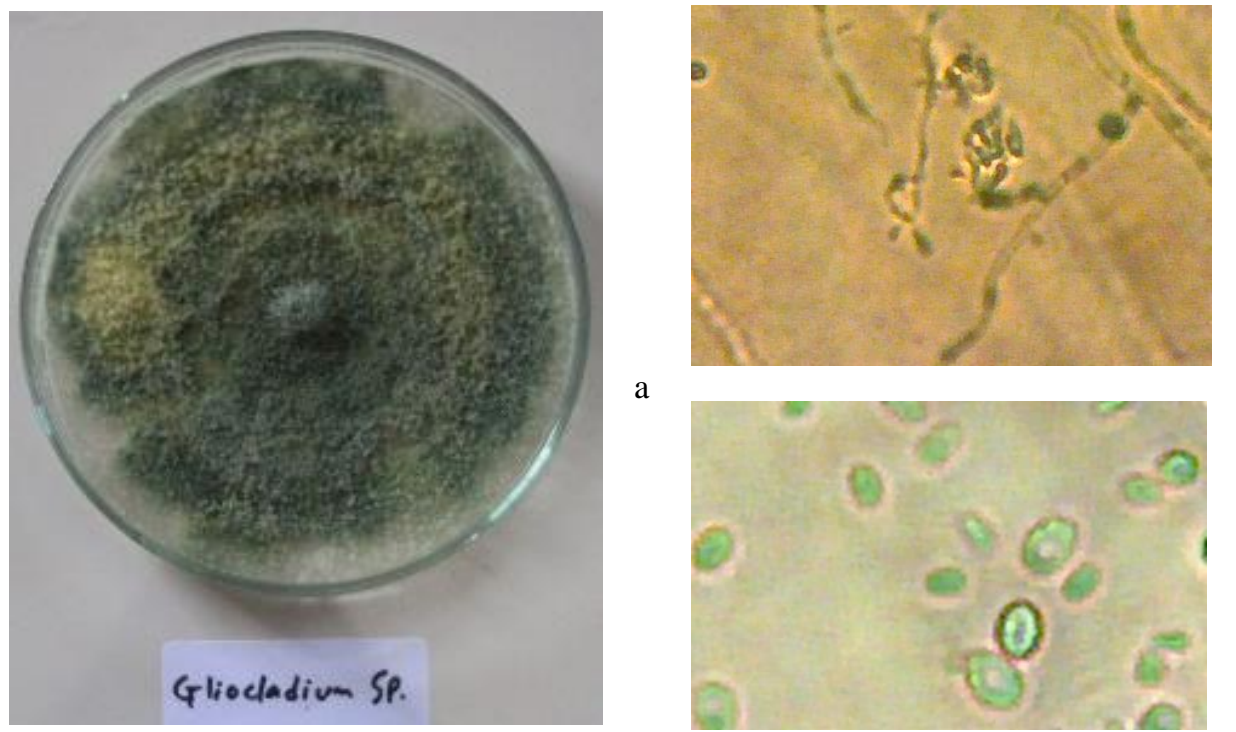

Figure 3.

(a) Colony Gliocladium pada PDA, (b) form phialides and (c) form conidia

The B. theobroma fungus has a gray color in its early stages of growth. This fungus has a shape like cotton and has abundant air between the mycelia. Conidiums are oval, one-insulated, dark in color and their exospores have pathways [14].

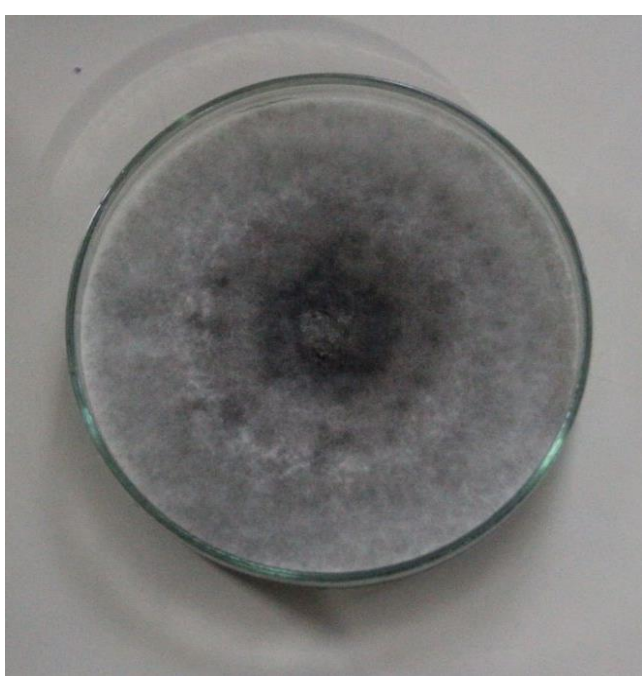

a

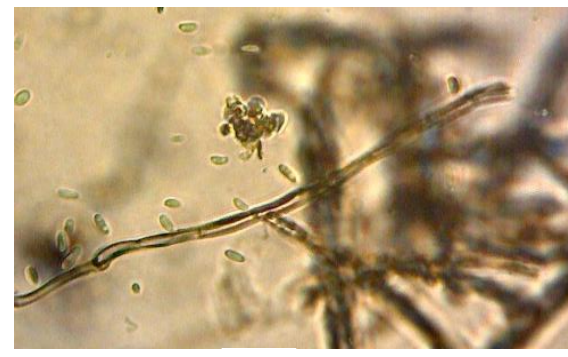

b

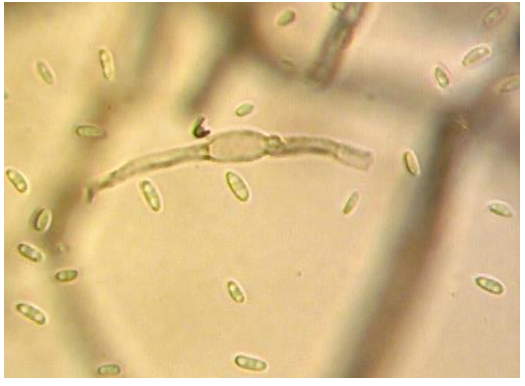

c

Figure 4.

(a) Colonies on PDA, (b) hyphae, (c) form conidia 

Disease (Botryodiplodia theobromae) in Grapefruit (Citrus grandis L. Osbeck)

\subsection{Colony Area}

The average area of $B$. theobromae colonies in $T$. atroviride treatment was $18.34 \mathrm{~cm} 2$, while the average in the treatment of Gliocladium $s p$. is equal to $22.25 \mathrm{~cm} 2$. The difference in the average area of the $B$. Theobromae colony was $3.91 \mathrm{~cm} 2$.

Table 1.

Colony Area

\begin{tabular}{ll}
\hline Treatments & $\begin{array}{l}\text { Average Colony Area } \\
\left(\mathbf{c m}^{2}\right)\end{array}$ \\
\hline T. atroviride & 18,34 \\
Gliocladium sp. & 22,25 \\
\hline
\end{tabular}

\subsection{Growth Rate}

Tabel 2

Growth rate

\begin{tabular}{llll}
\hline \multirow{2}{*}{$\begin{array}{l}\text { Days After } \\
\text { Inoculation }\end{array}$} & \multicolumn{3}{l}{ Colony Area $\left(\mathbf{c m}^{2}\right)$} \\
\cline { 2 - 4 } & T. atroviride & Gliocladium sp. & B. theobromae \\
\hline 1 & 1.13 & 0.79 & 1.13 \\
2 & 5.72 & 4.91 & 16.61 \\
3 & 22.89 & 28.26 & 54.08 \\
4 & 48.99 & 60.79 & 75.46 \\
5 & 78.50 & 75.46 & 78.50 \\
\hline
\end{tabular}

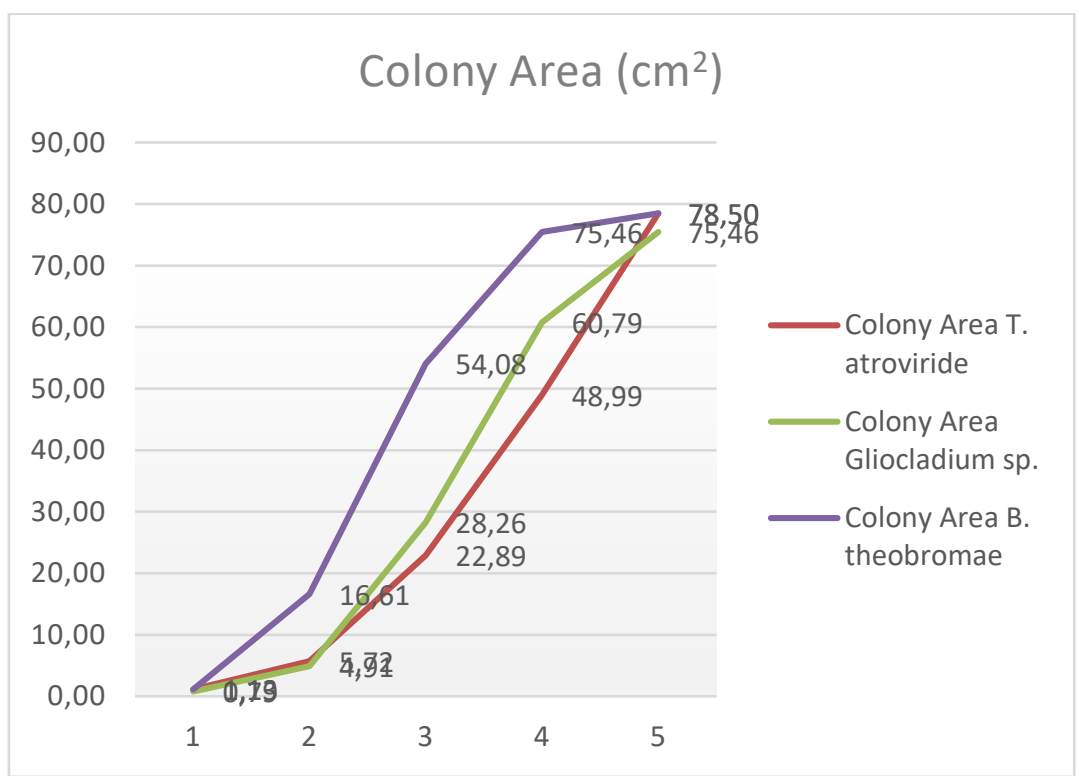

Figure 5.

Colony area growth rate

The colony area of each fungus on the first day after inoculation), the colony area of $B$. theobromae and $T$. atroviride was $1.13 \mathrm{~cm} 2$, while Gliocladium $s p$. As big as $0.79 \mathrm{~cm} 2$. Furthermore, two days to four days $B$. theobromae experienced a rapid growth rate and the fifth day almost covered the entire petri dish, namely $75.46 \mathrm{~cm} 2$. For the colony area of $B$. theobromae, it experienced a very fast growth rate, beating $T$. atroviride on the third and fourth days. The growth of the fungus Gliocladium sp. reduced on the fifth day. 


\subsection{Antagonism Mechanism}

T. atroviride and Gliocladium sp. competed from the third day of the in-vitro test and inhibited fungal pathogens through antibiosis which contained space on the petri dish (Figures 6. a and c). After the third day, T. atroviride and Gliocladium sp. whose hyphae had met, parasitism began and continued to suppress the diameter colony of $B$. theobromae (Figures 6.b and d).

Tabel 3.

Antagonism Mechanism

\begin{tabular}{llll}
\hline Treatments & Competition & Antibiosis & Parasitism \\
\hline T. atroviride & + & + & + \\
Gliocladium sp. & + & + & + \\
\hline
\end{tabular}

The antagonist fungi $T$. atroviride and Gliocladium $s p$. these compounds have secondary metabolites and the ability to parasitize pathogenic fungi. Trichoderma $s p$. has an antibiosis mechanism that produces secondary metabolites in suppressing pathogenic fungi. Hyphae of Trichoderma spp. produce chitinase, glucanase, and protease enzymes which can degrade the host hyphae during parasitism. In figure 6 (b). shows space because of the metabolite compounds produced by $T$. atroviride. Gliocladium $s p$. produces gliotoxin which can inhibit the growth of pathogenic fungal mycelia [15]. Gliotoxin can inhibit the growth of pathogenic fungi and create space in Figure 6 (a and c).

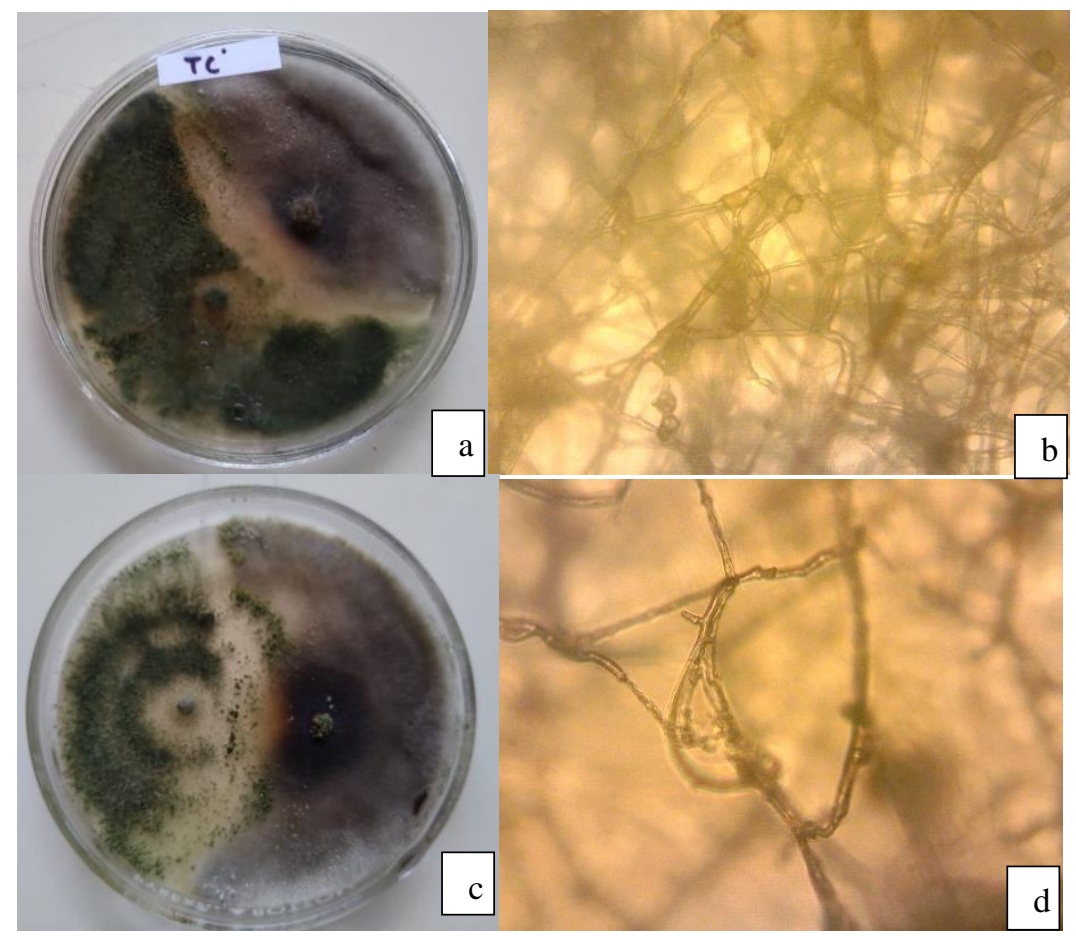

Gambar 6.

Antagonism test (a) T. atroviride, (b) Hyphae of the T. atroviride antagonism test, (c) Gliocladium sp., (d) Hyphae of the Gliocladium sp. antagonism test.

\subsection{Inhibition}

The results of the statistical analysis on the average inhibition test were $94.58 \%$ for $T$. atroviride and $81.67 \%$ for Gliocladium $s p$. at the level of $\alpha=5 \%$, the analysis shows a significant effect. The difference in the average inhibition power is $12.92 \%$. 
Tabel 4

Rata-rata daya hambat dalam \%

\begin{tabular}{ll}
\hline Perlakuan & $\begin{array}{l}\text { Daya Hambat } \\
(\mathbf{\%})\end{array}$ \\
\hline T. atroviride & 94,58 \\
Gliocladium sp. & 81,67 \\
\hline
\end{tabular}

Gliocladium $s p$. and T. atroviride in the antagonism test grew rapidly so that the fungus $B$. theobromae was pressed. On the third day, the dual culture of antagonistic fungi and pathogenic fungi had suppressed each other. Growth of the fungus T. atroviride and Gliocladium sp. is getting faster. Thus, the fungus $B$. theobromae is pressed and its diameter is getting smaller. This is because these antagonistic fungi have secondary metabolite compounds and the ability to parasitize pathogenic fungi.

\section{Conclusion}

Trichoderma atroviride and gliocladium sp. can suppress the growth of pathogenic fungi Botryodiplodia theobromae by $94.54 \%$ and $81.67 \%$, respectively so that it has an average difference of $12.87 \%$. At the growth rate, the fungus Botryodiplodia theobromae grew faster than the antagonistic fungi Trichoderma atroviride and Gliocladium sp.

\section{Acknowledgments}

Thank you to the Head of the Bali Province Food Crops and Horticulture Protection Center for providing the facilities to carry out this research.

\section{References}

[1] Soelarso, R.B. 1996. Budidaya Jeruk Bebas Penyakit. Kanisius, Yogyakarta.

[2] Semangun, Haryono. 2008. Penyakit-Penyakit Tanaman Perkebunan di Indonesia. Gadjah Mada University Press, Yogyakarta.

[3] Meliola. 2009. Pengantar Ilmu Penyakit Tumbuhan. Gajah Mada University Press. Yogyakarta.

[4] Uruilal C, Talahaturuson A, Rumahlewang W dan Patty J. 2017. Isolasi Trichoderma spp. dan Daya Antagonismenya Terhadap Scelotrium Rolsii Sacc. Penyebab Penyakit Layu Pada Tanaman Cabai (Capsicum anuum) Secara In-vitro. J: Budidaya Pertanian. 13(2): 64-67.

[5] Vinale Francesco, Sivasithamparam Krishnapillai, Ghisalberti Emilio L, Woo Sheridan L, Nigro Marco, Marra Roberta, Lombardi Nadia, Pascale Alberto, Ruocco Michelina, Lanzuise Stefania, Manganiello Gelsomina, Lorito Matteo. 2014. Trichoderma Secondary Metabolites Active on Plants and Fungal Pathogens. The Open Mycology Journal, 8, (Suppl-1, M5) 127-139.

[6] Rifai, MA. 1969. A Revision of The Genus Trichoderma. Mycological Paper. 116:1-56

[7] Herlina L. 2013. Uji Potensi Gliocladium sp Terhadap Pertumbuhan dan Produksi Tanaman Tomat. Biosaintifika 5 (2):88-93

[8] Benhamou N, and Chet I. 1993. Hyphal Interactions between Trichoderma harzianum and Rhzoctonia solani: Ultrastructure and Gold Cytochemistry of the Mycoparasitic Process. Phytopathology 83:1062-1071

[9] Baker, K. F. dan R. J. Cook. 1982. Biological control of plant pathogens. W.H. Freeman \& co. San Fransisco.

[10] Fokkema NJ, Meuleun F. 1976. Antagonism of yeast like phyllosphere fungi against wheat leaves. Neth J . Plant Pathol. 82:13-16.

[11] Kubicek PC and Harman GE. 2002. Trichoderma and Gliocladium Volume 1. Taylor \& Francis. Bristol

[12] Samuels GJ, Dodd SL, Gams W, Castlebury L, Orlando P. 2002, Trichoderma species associated with the green mold epidemic of commercially grown Agaricus bisporus. Mycologia 94(1) : 146-170. 
Antagonism Test of Trichoderma atroviride and Gliocladium sp. Bali Local Isolates as a Control of Blendok Disease (Botryodiplodia theobromae) in Grapefruit (Citrus grandis L. Osbeck)

[13] Domsch K.H., W. Gams and T.H. Anderson. 2007. Compendium of soil fungi. Second Edition, IHWVerlag, Germany.

[14] Semangun, Haryono. 2007. Penyakit-penyakit Hortikultura di Indonesia (edisi kedua). Gajah Mada University Press. Yogyakarta

[15] Howell, C. R. 2003. Mechanisms employed by Trichoderma species in the biological control of plant diseases: the history and evolution of current concepts. Plant Disease 87 (1) : 4- 10. 